\title{
A escavação de Megiddo e a descoberta da tumba real
}

\author{
José Ademar Kaefer*
Élcio Valmiro Sales de Mendonça** \\ José Ademar Kaefer*
Élcio Valmiro Sales de Mendonça**
}

\section{Resumo}

Temos poucas informações a respeito do contexto cananeu prévio a Israel. A maior fonte são as cartas de Tell el-Amarna, que revelam que no século XIV AEC e, provavelmente, nos séculos subsequentes, Canaã se encontrava organizada em cidadesEstado (MORAN, 1992; RAINEY, 2015; KAEFER, 2018, p. 121-140). Contudo, qual a origem da população que vivia nas cidades-Estado, quem governava essas cidades, se a população das planícies e a população das montanhas eram da mesma etnia?, essas são perguntas que ainda carecem de resposta. De maneira que este artigo pretende ser uma pequena contribuição na busca dessas respostas. Ele terá como centro de sua apresentação o histórico das escavações do sítio arqueológico de Megiddo (Tel Megiddo), a tumba real ali descoberta em 2016 e a possível contribuição dessa descoberta para o estudo de Canaã prévio a Israel.

Palavras-chave: Arqueologia. Bíblia. Megiddo. Escavações. Tumba real.

\section{The excavation of Megiddo and the discovery of a royal tomb}

\section{Abstract}

We have little information about the Canaanite context before the emergence of Israel. The largest sources are the Tell el-Amarna letters, which reveal that in the fourteenth century BCE and probably in subsequent centuries, Canaan was organized into citystates (MORAN, 1992; RAINEY, 2015, KAEFER, 2018, p. 121-140). However, the origin of the population living in the city-states, who ruled these cities, whether the population of the plains and the population of the mountains were of the same

* Universidade Metodista de São Paulo. http://orcid.org/0000-0003-1607-2810

URL http://www.cbiblicoverbo.com.br .e-mail: jademarkaefer@yahoo.com.br .

** Doutor em Ciências da Religião (UMESP). Professor da Graduação em Teologia da Universidade Metropolitana de Santos (UNIMES) e Professor de Hebraico Bíblico no curso de Línguas Bíblicas da Faculdade de Teologia da Igreja Metodista do Brasil (Fateo/ UMESP). Atualmente concentra suas pesquisas em dialetologia e epigrafia hebraica.

E-mail: elcio.mendonca@hotmail.com.br. 
ethnic group?, are questions that still need to be answered. So, the present article pretends to be a small contribution in the search of these answers. It will focus on the excavation of the archaeological site of Megiddo (Tel Megiddo), the royal tomb there discovered in 2016 and the possible contribution of this discovery to the study of Canaan prior to Israel.

Keywords: Archaeology. Bible. Megiddo. Excavations. Royal tomb.

\section{La excavación de Megiddo y el descubrimiento de la tumba real}

\section{Resumen}

Tenemos pocas informaciones sobre el contexto cananeo previo a Israel. La mayor fuente son las cartas de Tell el-Amarna, que revelan que en el siglo XIV AEC y, probablemente, en los siglos siguientes, Canaán se encontraba organizada en ciudadesEstado (MORAN, 1992; RAINEY, 2015; KAEFER, 2018, p. 121-140). Sin embargo, ¿cuál era el origen de la población que vivía en las ciudades-Estado, quién gobernaba estas ciudades, si la población de las llanuras y la población de las montañas eran de la misma etnia?, son preguntas que aún necesitan de respuestas. De manera que, el presente artículo pretende ser una pequeña contribución en la búsqueda de estas respuestas. El tendrá como centro de su presentación el histórico de las excavaciones del sitio arqueológico de Megiddo (Tel Megiddo), la tumba real allí descubierta en 2016 y la posible contribución de este descubrimiento para el estudio de Canaán previo a Israel. Palabras clave: Arqueología. Biblia. Megiddo. Excavaciones. Tumba real.

\section{Introdução}

Em junho e julho de 2016 participei, com alguns orientandos meus, da escavação arqueológica no Tel Megiddo (Megiddo Expedition, 2016). ${ }^{1}$ Essa possibilidade surgiu durante a etapa final do meu pós-doutorado realizado no Departamento de Arqueologia da Universidade de Tel Aviv, sob a orientação do arqueólogo e prof. Israel Finkelstein. A escavação não tinha maiores pretensões de minha parte, senão a de encorpar a pesquisa dos sítios arqueológicos de Israel, Palestina e Jordânia, dos períodos do Bronze e do Ferro, pesquisa essa a que venho me dedicando nos últimos seis anos, com o meu grupo de pesquisa "Arqueologia do Antigo Oriente Próximo". 3 Evidentemente que também se apresentava a oportunidade de poder participar da escavação em um dos sítios mais cobiçados pelos

\footnotetext{
1 https://sites.google.com/site/megiddoexpedition/dig-megiddo-2016 e https:// megiddoexpedition.wordpress.com/ http://dgp.cnpq.br/dgp/espelhogrupo/4338921870858325

http://portal.metodista.br/arqueologia; https://metodista.academia.edu/JoséAdemarKaefer
} 
arqueólogos de todo Levante e que tem uma história de mais de um século de escavações e investigações (FINKELSTEIN, USSISHKIN, HALPERN, 2006; KAEFER, 2012, p. 27-30). Megiddo se transformou numa espécie de laboratório para estudo das novas datações da história do Israel bíblico. O fator que determina essa importância é a excelência da estratigrafia desse sítio. Apresentar o histórico das escavações desse sítio, a descoberta da tumba real ali por nós e a possível contribuição dessa descoberta para a compreensão do contexto cananeu prévio a Israel serão as metas deste manuscrito.

\section{Megiddo}

Megiddo está localizada no centro da maior área fértil de Canaã, o Vale de Jezreel, ${ }^{4}$ também conhecido como Vale de Esdrelon ${ }^{5}$ (KAEFER, 2016, p. 25-38), junto a duas fontes, que no passado supriam água suficiente para a manutenção da população que vivia na fortaleza. Uma fonte fica do lado leste do monte ('ein Megiddo), a qual ainda contém água, e a outra do lado oeste. Da última foi construído um sofisticado sistema de água durante o Ferro II, com uma escada vertical de 30 metros e um túnel horizontal de 50 metros, que levava até a fonte. Além disso, Megiddo está situada junto a uma das mais importantes vias comerciais internacionais de todo Antigo Oriente e foi habitada quase continuamente por seis milênios (USSISHKIN, 2018, p. 9). Dada a localização estratégica para o controle da região, voltada para o Vale de Jezreel, Megiddo foi palco de permanentes disputas e guerras durante toda a sua existência. ${ }^{6}$ A última batalha levada a cabo ali foi em 1918 da nossa era, entre ingleses e turcos otomanos. As constantes guerras, que geraram destruições e reconstruções contínuas por diferentes povos, permitem uma leitura bastante precisa dos períodos estratigráficos (FINKELSTEIN, 1996, p. 170-184). De aí a importância de Megiddo para a arqueologia. Ou seja, a guerra, que é ruim para o povo, é excelente para a arqueologia. De forma que a escavação de Megiddo se tornou um referencial para a compreensão da história do Israel bíblico. Ela está no centro do debate quando o assunto é história de Israel. ${ }^{7}$

\footnotetext{
$4 \quad$ Cf.: Js 17,$16 ;$ Jz 5,15; 6,33; 7,1.8.12; Os 1,5; 1 Mc 12,49 .

5 Cf.: Jt 3,9.

6 Provavelmente, foi esse o fator que fez de Megiddo ser o local escolhido para o Armagedon, onde aconteceria a última batalha entre os reis da terra e os anjos de Deus (Ap 16,13-16).

Como um exemplo da importância do Tel, em 5 de janeiro de 1964, o papa Paulo VI visitou Megiddo, onde foi recebido numa cerimônia oficial por autoridades locais. Único sítio arqueológico em Israel, até hoje, a receber a visita de um papa.
} 


\section{As escavações no Tel Megiddo}

O sítio arqueológico Tel Megiddo (Tell el-Mutesellim ${ }^{8}$ ) foi identificado como a Megiddo bíblica ${ }^{9}$ em 16 de junho de 1838, por Edward Robinson, durante sua viagem de pesquisa ao Egito e Palestina (ROBINSON, v. II, 1856, p. 328-330; MENDONÇA, 2017, p. 178). Como havia dificuldades para a localização do sítio, por causa dos nomes árabes e otomanos dados aos antigos locais bíblicos, Robson se baseou nas informações de Eusébio e Jerônimo, do século $\mathrm{V}$, segundo os quais Megiddo ficaria a poucos quilômetros de Taanach. Robinson teve sucesso na identificação, mas não realizou qualquer escavação no sítio.

A primeira expedição arqueológica em Megiddo aconteceu somente no início do século XX, entre os anos 1903-1905, num projeto financiado pelo Kaiser alemão Wilhelm II e conduzido pela Deutcher Palästina-Verein (Associação Alemã para a Exploração da Palestina). Uma vez que Berlim mantinha boas relações diplomáticas com o governo otomano, a associação alemã não teve dificuldades para conseguir a autorização e iniciar as escavações no Tell el-Mutesellim (DAVIS, 2004, p. 36). O engenheiro e arqueólogo Gottlieb Schumacher, que morava em Haifa, foi indicado para dirigir as escavações. Schumacher era de família alemã, nascido em Ohio, nos EUA, que se havia mudado para Haifa num projeto de colonização da Palestina, no final de 1860. Depois de estudar engenharia em Stuttgart, Alemanha, Schumacher retornou para Haifa, onde foi nomeado engenheiro chefe na cidade de Akko pelo governo otomano. ${ }^{10}$ Esse currículo qualificava Schumacher ${ }^{11}$ para assumir a direção da primeira expedição arqueológica no Tell el-Mutesellim, posteriormente chamado de Tel Megiddo.

A escavação foi feita com técnicas ainda bastante rudimentares. Empregavam-se muitos trabalhadores com pouca qualificação na arte da arqueologia. Conforme o diário, escrito em alemão, do professor Emil Kautzsch, que visitou as escavações em 1904, eram empregados diariamente cerca de setenta trabalhadores e trabalhadoras, duas terças partes eram

\footnotetext{
Em turco otomano "colina do governador" (GERBER, 1994, p. 137).

Js 17,11; Jz 1,27; 5,19-21; 1Rs 9,15-19; 2Rs 9,27; 23,29-30; 1Cr 7,29.

10 Cf.: https://www.pef.org.uk/profiles/gottlieb-schumacher. Acesso em: 23/10/2018.

11 A experiência de Schumacher em escavações, contudo, era bastante limitada, reduzia-se à participação na escavação do Tel Taanach, com Ernst Sellin. Após Megiddo, Schumacher participou na escavação da Samaria, em 1908, num projeto coordenado pela Universidade de Harvard (USSISHKIN, 2018, p. 32).
} 
mulheres e meninas, cujo principal trabalho era carregar a terra para fora do sítio, algumas vezes também peneirá-la, enquanto os homens cavavam (USSISHKIN, 2018, p. 36).

Com poucos supervisores arqueólogos, os aspectos estritamente arqueológicos ficavam todos por conta de Schumacher, com consequências desastrosas para os resultados, principalmente no que se refere à datação da estratigrafia. O método utilizado era a escavação vertical, em forma de trincheira (FUNARI, 2010, p. 66). De maneira que foi escavada uma longa trincheira que cortou o sítio pelo centro, de norte a sul. Schumacher encontrou parte da fortaleza norte e centro do Tel, bem como, o palácio norte, a casa dos portões e o templo das estelas, onde a escavação teve início. Um dos achados mais importantes dessa expedição foi o conhecido selo de Jeroboão II, no qual se encontra a inscrição "Shema, servo de Jeroboão", e que foi datado do século VIII AEC. A maior parte dos achados era levada para o museu de Berlim e o restante, uma pequena parte, para o museu de Constantinopla pelo comissário otomano (USSISHKIN, 2018, p. 36-37).

Depois da escavação alemã, as escavações no Tell el-Mutesellim foram interrompidas até o final da Primeira Guerra Mundial. Em 1918, a cavalaria do exército britânico, sob o comando do general Lord Allenby, ${ }^{12}$ derrotou junto a Megiddo o exército turco otomano. É também durante a Primeira Guerra Mundial, especificamente em 1917, que foi tirada a primeira foto aérea do sítio, evidentemente por interesses militares, pela aviação alemã, que defendia a ocupação otomana. Apesar da baixa qualidade, é possível ver na foto as trincheiras escavadas por Schumacher (USSISHKIN, 2018, p. 20-21). Após a expulsão dos turcos e com a ocupação inglesa, inicia-se o chamado Mandato Britânico da Palestina. Começa, então, uma nova fase nas escavações, do agora chamado "Monte do Armagedon" (DAVIS, 2004, p. 59).

\subsection{A grande escavação do Instituto Oriental de Chicago}

O Instituto Oriental de Chicago escavou o Tel Megiddo sucessivamente por treze anos, de 1925 a 1938, e só foi interrompido por causa do início da Segunda Guerra Mundial. Foi a maior escavação já levada a cabo em um sítio arqueológico do período bíblico. O sonho desde estudante do fundador do instituto, o egiptólogo James Henry Breasted, era

12 Cujo neto daria, décadas depois, um grande apoio aos projetos de escavação da equipe da Universidade Tel Aviv. 
escavar Megiddo. De aí é possível compreender o grande investimento feito na escavação. O projeto foi financiado por John Davison Rockefeller Jr, cujo museu se encontra hoje em Jerusalém, construído com doação em 1929.

A escavação do Instituto Oriental de Chicago pode ser dividida em três períodos, cada um dirigido por um diretor diferente. De 1925-1927, por Clarence Stanley Fisher; de 1927-1935, por Philip Langstaffe Ord Guy; de 1935-1938, por Gordon Kenneth Loud.

\subsubsection{A escavação de Clarence Stanley Fisher: 1925-1927}

Clarence Fisher (1925-1927), um arqueólogo com larga experiência, já havia escavado no Egito, Samaria e Betsã, introduziu um novo método na maneira de fazer arqueologia. Ao invés de escavar por trincheiras, método empregado por Schumacher e Macalister, o último em Gezer, Fisher optou por escavar grandes áreas horizontais, centímetro por centímetro e estrato por estrato (CLINE, 2017, p. 209). Isso possibilitava que se conhecesse melhor cada estrato e se identificasse com maior precisão onde cada artefato estava localizado, ou seja, a que período pertencia. Fisher já havia utilizado esse método com George Andrew Reisner, quando escavaram Samaria (Sebastia). E, por isso, esse método ficou conhecido como Método ReisnerFisher, o qual se tornou, posteriormente, o modelo para as escavações futuras por vários anos (DAVIS, 2004, p. 59; MENDONÇA, 2017, p. 179).

Fisher não teve muito tempo para realizar seu projeto, pois adoeceu. A construção da infraestrutura para acolher o gigantesco projeto parece que lhe tomou muito tempo. Depois de estabelecer a medição de todo o monte, Fisher concentrou o trabalho no lado sudeste do monte, onde chegou a escavar até o estrato israelita (V). Ali escavou alguns edifícios, que já haviam sido encontrados por Schumacher, ${ }^{13}$ por exemplo, o palácio leste. Fisher encontrou na parte sul desse palácio dois altares de incenso de quatro chifres, ambos quebrados.

Fisher contraiu malária, ${ }^{14}$ como muitos trabalhadores, e acabou sendo substituído por Philip Guy, dois anos após o início do seu trabalho.

\footnotetext{
13 Ainda que, ao que se sabe, a relação de Fisher com Schumacher não era das melhores. Em sua passagem por Haifa, em 1925, nem sequer se deu ao trabalho de visitálo (USSISHKIN, 2018, p. 48).

14 Provavelmente, por construir inicialmente o acampamento junto à fonte norte 'ein Megiddo, onde abundavam os mosquitos transmissores.
} 


\subsubsection{A escavação de Philip Langstaffe Ord Guy: 1927-1935}

Philip Guy, que havia trabalhado como assistente na escavação de Tell el-Amarna (MYNAROVÁ, 2015, p. 37-46), escavou de maio de 1927 a junho de 1935. Foi o tempo mais longo e em maior escala. Foi Philip Guy quem começou sistematicamente a escavação de todo o Tel, um estrato após o outro. ${ }^{15} \mathrm{E}$, em junho de 1935 , ele alcançou em três grandes áreas o estrato VI, considerado o estrato cananita, que fica logo abaixo do chamado estrato israelita, estrato V (USSISHKIN, 2018, p. 57). A maior parte das grandes estruturas do período dos reis de Israel foi escavada sob a coordenação de Guy, como os estábulos norte e sul, atribuídos erroneamente ao rei Salomão (LAMON; SHIPTON, 1939; $;^{16}$ FRANKLIN, 2018, p. 190-192), ${ }^{17}$ e o sistema de águas. Outras grandes obras, já iniciadas por Schumacher e Fisher, foram completadas por Guy, como os palácios leste e sul. Guy também introduziu em Megiddo o uso de balões para tomar fotografias aéreas, o que possibilitava uma melhor visão do conjunto do Tel (DAVIS, 1987, p. 76). Era um trabalho incomensurável, que no dia a dia da escavação contava em torno de duzentas pessoas, conforme diz uma carta que Guy escreveu a Breasted, em 23 de setembro de 1934.

Mas, as relações entre Philip Guy e o diretor do Instituto de Chicago, Henry Breasted, não eram boas e se deterioram com o passar do tempo. Breasted achava que a escavação estava indo muito lenta e ele queria chegar ao nível abaixo do israelita para encontrar os grandes monumentos egípcios, que ele achava existirem em Megiddo (USSISHKIN, 2018, p. 60-62). Philip Guy foi demitido em junho de 1935 e em seu lugar foi contratado Gordon Kenneth Loud.

\subsubsection{A escavação de Gordon Kenneth Loud: 1935-1938}

Gordon Loud tinha larga experiência em arqueologia, já havia escavado no Egito e na Assíria. Contudo, ele desconhecia completamente a arqueologia, o terreno, a cultura, a história etc. da Palestina. Esse fato, somado ao interesse megalomaníaco de Breasted, de escavar todo o Tel e de querer a todo custo

15 O objetivo inicial do Instituto Oriental de Chicago era escavar a totalidade do sítio, camada após camada. Quando chegaram ao período assírio, deram-se conta do tamanho da empreitada, sendo obrigados a desistir do projeto inicial. Começaram então focar em três áreas principais.

${ }^{16}$ Cf. https://m.tau.ac.il/ archpubs/megiddo/archmag.html (Acesso em: 23/10/2018).

${ }_{17}$ Guy se fundamentou em 1Rs 19,15 e 10,26, assim como, mais tarde, Yigael Yadin. 
chegar ao nível da presença egípcia, fizeram que a mudança de diretor fosse um desastre para Megiddo. Ou seja, em tese, o interesse de Breasted não era necessariamente fazer arqueologia, mas escavar monumentos. Essa parece ter sido a causa do conflito com Guy, que trabalhava por uma arqueologia mais técnica, lenta e apurada.

Gordon Loud retomou a técnica de escavar longas e largas trincheiras até tocar a base rochosa, que favorecia a busca por grandes monumentos. Ele já havia empregado essa técnica em Khorsabad, na Assíria. Em Megiddo, Gordon escavou três trincheiras de 50-70 metros de comprimento por 6 metros de largura em três áreas diferentes, até tocar a base rochosa, destruindo todos os estratos superiores para alcançar o inferior. Isso causou muitos estragos para estudos futuros do sítio. Entre outros monumentos destruídos, está a asa direita do assim chamado "portão salomônico" de seis câmaras. ${ }^{18}$ Além de que, a pouca importância dada à cerâmica, entre outros, conduziu Gordon a graves erros na leitura da estratigrafia (USSISHKIN, 2018, p. 64-67).

Em todo caso, a área escavada por Gordon foi enorme, incluindo várias residências, palácio, muralhas, portões etc. No lado norte, a área $\mathrm{AA}$, ele alcançou até o nível do Bronze Médio. No lado leste, a área BB, área dos templos $(\mathrm{BB} / \mathrm{J})$, chegou até a base rochosa (LOUD, 1939). Essa área é impressionante, talvez a de maior destaque. Ali foram encontrados três templos construídos sucessivamente um sobre o outro. O último é o maior. No centro se encontra o grande altar redondo, que impacta o visitante assim que chega ao local. O altar teve duas fases: o primeiro era maior, media de 8-10 metros de diâmetro, e serviu de base para o segundo, um pouco menor, 8 metros de diâmetro, por 1.4 de altura, e uma escada com sete degraus (USSISHKIN, 2018, p. 70-71). Tudo indica que esse impressionante espaço serviu de centro de culto para a ampla população que ocupava o Vale durante o Bronze Antigo IB (3400-3000). Junto ao altar foram encontrados vários ossos de animais grandes e pequenos. ${ }^{19}$

\footnotetext{
18 Local esse onde escavamos na temporada jun./jul. 2018, em busca do "portão perdido" do Ferro I. Como a Secretaria de Turismo de Israel pretende reconstruir a asa direita do referido portão de seis câmaras, Israel Finkelstein, que atualmente coordena as escavações em Megiddo, apressou-se em organizar um projeto, em 2017, para escavar a área, antes que a asa fosse reconstruída, em busca de um quarto portão que fazia falta no complexo dos portões da entrada da cidade. A sorte novamente foi nossa companheira e o portão foi encontrado. Mas, esse é assunto para outro manuscrito.

19 Nesse período, a região dos arredores de Megiddo era muito habitada. Na transição do Bronze Antigo IB para o Bronze Antigo II há uma grande lacuna de presença humana. A causa do fim da ocupação ainda é desconhecida.
} 
A área dos templos $(\mathrm{BB} / \mathrm{J})$. Ao centro, o grande altar redondo da era do Bronze Antigo

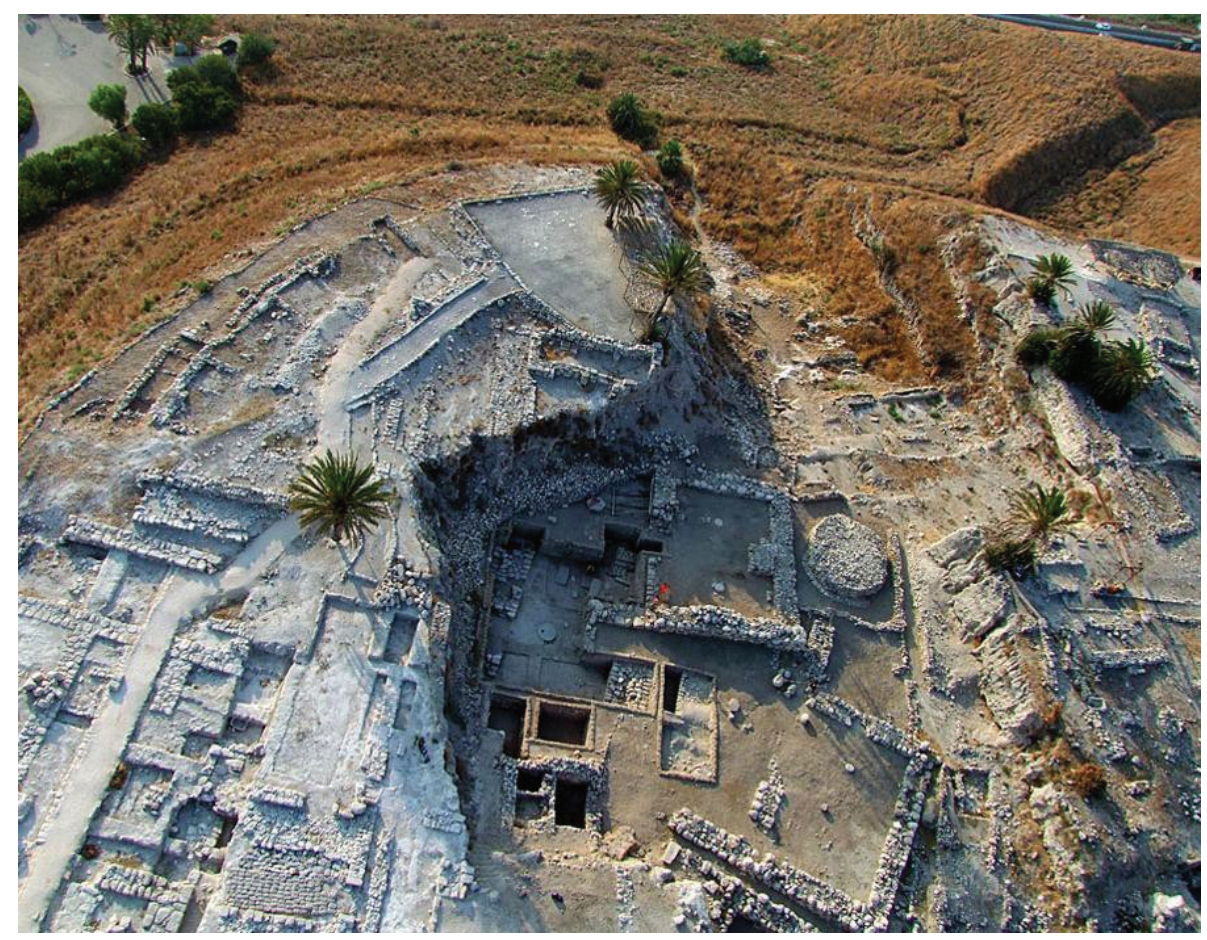

(Foto: gentileza de Israel Finkelstein).

O feito inédito de escavar parcialmente todo o Tel é facilmente perceptível na vista panorâmica, com destaque para a área dos portões, a grande depressão na parte leste, conhecida como área BB, e o sistema de águas. Como amostra do intenso trabalho realizado pela expedição de Chicago, basta observar o monte artificial que foi formado na base do lado sudoeste do Tel, resultado das toneladas de terra carregadas para fora das escavações. "Apesar de suas limitações, as escavações conduzidas em Megiddo pela expedição do Instituto Oriental de Chicago fez algumas das mais importantes descobertas já feitas na terra de Israel e estabeleceu o Tel Megiddo como sítio chave da Arqueologia Bíblica” (USSISHKIN, 2018, p. 71).

Parte dos artefatos encontrados pela expedição de Chicago permanece em exposição no Museu Rockefeller, em Jerusalém. Os achados estão agrupados por períodos e permanecem nas estantes do museu, na área onde estão expostos os achados da Idade do Ferro e do Bronze. 
As escavações no Tel Megiddo tiveram que ser interrompidas novamente por conta do início da Segunda Guerra Mundial (1939-1945) e só foram retomadas nos primeiros anos da formação do Estado de Israel, por Yigael Yadin, da Universidade Hebraica de Jerusalém. ${ }^{20}$

\subsection{A escavação da Universidade hebraica de Jerusalém}

Durante os anos de 1960, 1966-1967 e 1971-1972, a Universidade hebraica de Jerusalém realizou escavações em Megiddo. Foram temporadas bastante breves, com grupos bem reduzidos e coordenados pelo arqueólogo e professor Yigael Yadin. ${ }^{21}$ Com Yadin se inicia um novo período na arqueologia da Palestina. Uma vez que as expedições arqueológicas passam a ser agora controladas e em parte financiadas pelo novo Estado de Israel, passam a ter também uma finalidade político-ideológica, a de legitimar a ocupação da terra.

Yadin havia construído e publicado uma teoria de que os portões de seis câmaras encontrados em Megiddo, Hazor e Gezer foram todos edificados pelo rei Salomão, confirmando, assim, o que diz 1Reis 19,15 e 10,26 (YADIN, 1958 , p. $80-86 ; 1960$, p. 62-68; 1970, p. 66-96). Esse achado e a teoria de Yadin se tornaram o principal argumento para fundamentar, via arqueologia e via texto bíblico, a teoria da grande Monarquia Unida, sob os reinados de Davi e Salomão, reis de Judá, vigente ainda até hoje. Contudo, o tendão de Aquiles da teoria de Yadin é que o chamado "portão de Salomão"22 se encontra unido ao muro da cidade, que, por sua vez, se encontra em cima do palácio de Salomão (palácio sul). Ou seja, o referido portão, evidentemente, tem que ser posterior ao palácio de Salomão. Para superar essa contradição, Yadin supôs que, sob o muro unido ao portão, deveria existir outro muro (um muro casamata), ${ }^{23}$ que teria passado desapercebido pela expedição de Chicago e que se encontrava no mesmo nível do portão e do palácio (USSISHKIN, 2018, p. 74). Mas, esse muro nunca foi encontrado.

20 Cf. https://sites.google.com/site/megiddoexpedition/the-site/excavations/pastexcavations. Acesso em: 23/10/2018.

21 Além de arqueólogo, Yigael Yadin foi chefe militar e vice-primeiro-ministro do Estado de Israel.

22 Cuja asa direita, como já visto, foi removida por Gordon Kenneth Loud.

23 Casamata é uma muralha dupla. 
Em síntese, as curtas temporadas das escavações de Yadin, basicamente, reduziram-se em examinar monumentos e áreas já escavadas anteriormente, com o principal objetivo de encontrar evidências para fundamentar sua teoria. Essas evidências nunca foram encontradas e sua teoria foi mais tarde rejeitada por arqueólogos da Universidade de Tel Aviv e os "portões de Salomão" atribuídos à dinastia omrida.

\subsection{A escavação da Universidade de Tel Aviv: 1992-2018}

Depois de Yadin, as escavações no Tel Megiddo permaneceram paradas até meados de 1992, quando passaram para a responsabilidade do Departamento de Arqueologia da Universidade de Tel Aviv, tendo à frente os arqueólogos David Ussishkin, Israel Finkelstein, Baruch Halpern, Eric Cline, Matthew J. Adams e Mario A. S. Martin. A coordenação das temporadas tem a seguinte ordem:

- De 1992-2008: David Ussishkin, Israel Finkelstein e Baruch Halpern.

- De 2009-2012: Israel Finkelstein, David Ussishkin e Eric H. Cline.

- De 2013-2014: Israel Finkelstein e Eric H. Cline.

- De 2014-2018: Israel Finkelstein, Matthew J. Adams e Mario A. S. Martin.

No decorrer destes já 26 anos de escavações, novas áreas foram abertas, antigas foram retomadas e algumas foram suspensas. Apresentamos, a seguir, um plano resumido das áreas.

As áreas H, K, F são áreas da encosta do monte. A área $\mathrm{H}$, no lado norte do Tel; a área $\mathrm{K}$, no lado oposto, lado sul-sudeste do Tel; e a área F, no lado nordeste do Tel, já na cidade baixa, à direita da área de onde se sobe para os portões da cidade alta. As áreas S, G, P e L ficam na mesma direção da área F, só que no alto do Tel. Essas áreas (S, G, P, L), com a área $\mathrm{H}$, onde se encontra o palácio do governador assírio, são as áreas onde vivia a nobreza (área dos palácios), no lado norte e nordeste do Tel. Ali sopra uma constante brisa suave, propícia para se morar. O interesse nas áreas $\mathrm{S}$, $\mathrm{G}$ e L era para completar a escavação dos palácios. Na área $\mathrm{P}$, o objetivo era limpar a monumental escadaria descoberta pela expedição de Chicago. A escadaria conduzia do alto do portão da cidade do ferro até a cidade baixa e sua provável função era a de levar até a fonte de água do lado leste ('ein Megiddo). A longa escadaria ainda é bem visível ao visitante, assim que ele sobe para o portão da cidade. 
A área $\mathrm{J}(\mathrm{BB} / \mathrm{J})$ é a área onde todas as expedições cavaram. Essa é a área sagrada ou área dos templos e altares, onde se localiza o grande altar circular, encontrado por Loud. Como já mencionado, é a área de maior impacto para o visitante. Ela foi salva pelo início da Segunda Guerra Mundial, pois Loud tinha a intenção de remover todos os estratos na temporada de 1939. Mas, quando estourou a guerra, a escavação foi abandonada e os templos mantidos.

Em 2012, foi iniciada uma nova e importante área, na parte sul do Tel, a área Q. Ali a Universidade de Chicago já havia escavado, mas somente até o estrato da presença assíria (estrato III). A nova escavação fazia parte de um grande projeto de quatro anos, financiado pelo Instituto Weizmann, de Israel. $O$ interesse se concentrava principalmente no estudo dos períodos do Ferro e do Bronze Tardio. De forma que essa área se tornou uma espécie de laboratório para comprovar as teorias de Israel Finkelstein sobre a alta e baixa cronologia da história de Israel (USSISHKIN, 2018, p. 79-96).

Tel Megiddo visto do lado norte

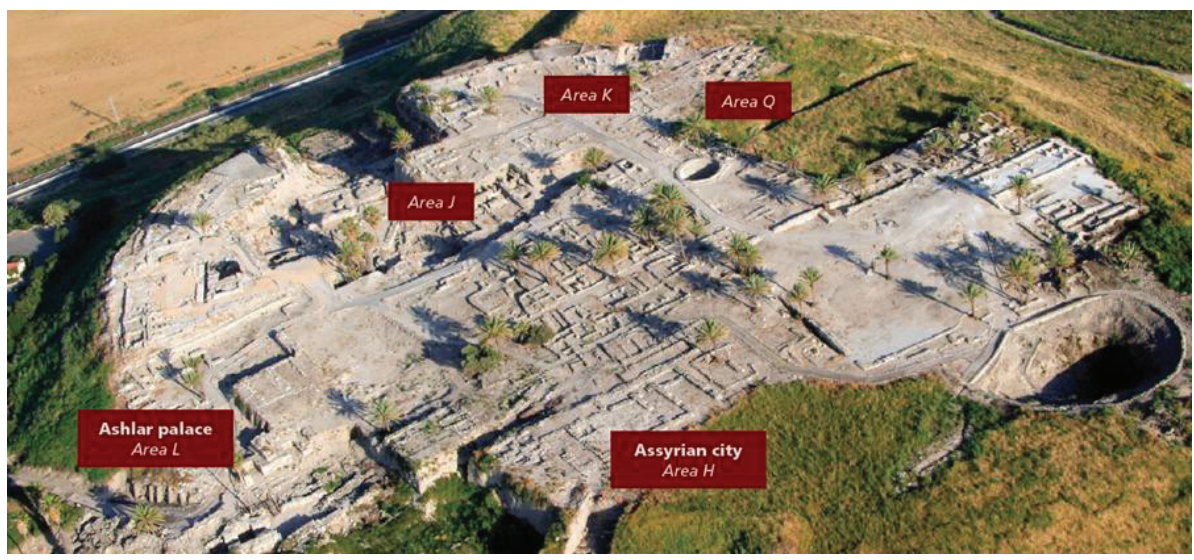

(Foto: gentileza de Israel Finkelstein).

Um particular sobre a área K, onde em 2016 escavaram meus, então, orientandos, Élcio V. Sales de Mendonça e Silvano Lessi Tisini. Essa área foi iniciada em 1994 e, desde então, teve escavação contínua em todas as temporadas. Atualmente, a escavação é coordenada pelo meu amigo Mario A. S. Martin ${ }^{24}$ (MARTINI, 2018, p. 267-286). Nessa área, foram

${ }^{24}$ Companheiro nas partidas de futebol, às tardes, após a lavagem da cerâmica. 
encontrados todos os estratos, desde o período do Ferro II, período da ocupação assíria (FRANKLIN, 2018, p. 189-208), até o período do Bronze Médio (por volta de 1700 AEC). A partir do Ferro I (por volta do ano 1000 AEC) foi encontrada uma enorme casa, com vários cômodos e uma pequena área central, que unia todos os cômodos. Era uma casa pertencente a uma família/s rica ${ }^{25}$ que subsistiu durante 700 anos. Ou seja, desde o Bronze Médio, 1700 AEC (estrato XI), até o ano 1000 AEC (estrato VIB), quando foi destruída por um enorme incêndio, que chegou a calcinar os blocos de adobe, tamanha intensidade do calor, e que destruiu todo o sítio. A destruição desse incêndio também é visível em outros sítios arqueológicos, como Hazor, cuja causa não se sabe exatamente (feito de Sheshong I? Povos do mar?). Portanto, a casa continuou em uso por 700 anos, sem ser destruída. O interessante é que durante o período do Bronze Tardio (1500-1200) foi introduzido um costume, que persistiu todo o período e depois se perdeu, de enterrar os mortos dentro de casa. Os corpos eram enterrados e depois de um tempo, quando já decompostos, os ossos eram colocados em uma tumba coletiva. Assim, foram encontrados vários corpos e ossos desse período enterrados dentro dos cômodos da casa grande.

O histórico de cada área e os artefatos encontrados pelo Departamento de Arqueologia da Universidade de Tel Aviv, nas temporadas de 1992 a 2008, estão muito bem documentados em seis volumes: "Megiddo III - 1992-1996 Seasons" (publicado no ano 2000, em dois volumes); "Megiddo IV - 1998-2002 Seasons" (publicado no ano 2006, em dois volumes); "Megiddo V - 2004-2008 Seasons" (publicado no ano 2013, em dois volumes). ${ }^{26}$

Além do uso de técnicas cada vez mais aperfeiçoadas no fazer arqueologia, o alto incremento de amostras para análise, via carbono 14, em diferentes laboratórios, o implemento de novas ciências, como o estudo do DNA etc., a equipe de Tel Aviv concentrou seus estudos em somente dois períodos: o Bronze Tardio e o Ferro. Ainda, reduziu de 100 para 25 anos cada estrato a ser analisado. Isso, evidentemente, resultou em mais trabalho, maior investimento econômico e mais tempo para o alcance dos resultados. Mas, os resultados das amostras se tornaram mais exatos e

\footnotetext{
25 Ainda que não pertencente à realeza, cujas moradias, como vimos, ficavam no lado oposto do Tel.

26 As séries foram coordenadas por Israel Finkelstein, David Ussishkin e Baruch Halpern.
} 
as datações mais precisas. Há ainda outro dado a ser mencionado, que foi a independência do fazer arqueologia dos interesses políticos e religiosos. Ou seja, separou-se a arqueologia da Bíblia e da política. De tudo isso nasceu uma nova arqueologia em Israel e Palestina.

Um dos resultados da nova arqueologia foi a teoria das novas cronologias do período bíblico, conhecida como a Baixa Cronologia (FINKELSTEIN, 2015, p. 85-87). A nova cronologia, baixada em torno de 60-80 anos, estabelecida a partir das pesquisas de Megiddo, está hoje no centro do debate, quando o assunto é arqueologia e história de Israel. Isso, evidentemente, tem consequências ideológicas para os interesses políticos do Estado, e Israel Finkelstein é apontado como causador principal dessa crise.

Enfim, o Tel Megiddo se tornou um sítio chave para o estudo, não só da história de Israel e Palestina, mas da história das populações que, por milênios, ocuparam essa região. Poder fazer parte da escavação ${ }^{27}$ dessa história, é sem dúvida um privilégio.

\subsection{O dia a dia da escavação}

A escavação arqueológica em um sítio como Megiddo exige uma complexa infraestrutura para abrigar todo o contingente humano e tecnológico. A expedição alemã, coordenada por Schumacher, estabeleceu seu acampamento no lado sul do Tel. A expedição de Chicago inicialmente se estabeleceu na base nordeste do monte, perto da fonte, e, mais tarde, no lado sudeste. A expedição da Universidade de Tel Aviv, por sua vez, ocupa sempre as instalações do Kibutz Mishmar Haemek, que dista cerca de $5 \mathrm{~km}$ do Tel. Foi ali que estivemos acomodados na temporada de 2016.

Ali, a rotina diária, como em qualquer escavação arqueológica, é bastante acelerada e o trabalho pesado. Levanta-se às 4h, pela manhã; às $4 \mathrm{~h} 45 \mathrm{~min}$ partem os dois ônibus, com muitos estudantes correndo, ainda com o copo de café na mão, para não perder a condução. O trajeto até o Tel leva cerca de 15 minutos. Chegando lá, cada grupo retira do bagageiro do ônibus as ferramentas de sua área, baldes para a coleta da cerâmica, instrumentos técnicos etc. e todos saem em uma longa fila, caminhando em silêncio, muitos, ainda sonolentos, sobem até o topo do sítio. Chegando no alto, o grande grupo se divide e cada um se dirige para a sua área. A escavação inicia bem na hora em que o dia começa a raiar.

27 Que já vai para a terceira temporada: 2016, 2018 e 2020. 
Essa preocupação em começar o trabalho quase de madrugada é para aproveitar as horas mais frescas do dia, uma vez que à tarde, o calor em Israel e Palestina é quase insuportável.

Por volta das $8 \mathrm{~h} 30 \mathrm{~min}$, todos interrompem o trabalho para um café reforçado, que é oferecido na base do Tel. Depois do café, que dura cerca de 45 minutos, o trabalho se estende até as 13 horas, quando todos regressam exaustos para o Kibutz. Chegando lá, é oferecido um suculento almoço, que, sem exagero, é tomado com voracidade. Depois do almoço tem um descanso até as 16 horas, quando todos se reúnem novamente, agora para lavar a cerâmica que foi coletada pela manhã. É um momento bonito de descontração juvenil, com muitas conversas e risos durante a lavagem. Esse momento dura em torno de uma a duas horas, dependendo da quantidade da cerâmica coletada, sobrando sempre um tempinho para um bom jogo de futebol para os esportistas mais aficionados ou um mergulho na piscina. Isso tudo antes da janta, que acontece às 19 horas. Depois da janta, às 20 horas, começam as aulas para os estudantes dos cursos de arqueologia. Às vezes, ainda tem palestras para todos os interessados. Esse é também o momento em que professores e especialistas aproveitam para analisar a cerâmica coletada no dia, separando a que interessa e descartando a que não tem valor. Às 22 horas encerram-se as atividades e todos vão para a cama.

\section{A descoberta da tumba real}

Os em torno de 75 participantes da expedição Megiddo 2016, entre estudantes e voluntários, foram distribuídos nas diferentes áreas de escavação. Cada área tinha um ou dois coordenadores ou coordenadoras e estava sob a coordenação geral do prof. Israel Finkelstein. F ui designado para a área $\mathrm{H}$, com um grupo de 12 pessoas. A área $\mathrm{H}$, por sua vez, foi dividida em quatro parcelas, com duas a quatro pessoas trabalhando em cada parcela. Comigo escavavam duas, às vezes três, jovens estudantes de arqueologia.

É importante lembrar que a área $H$ fica na chamada área nobre, na encosta do lado nordeste do Tel, cerca de vinte metros a oeste, onde Schumacher escavou um palácio em 1903-1905. A área H já estava sendo escavada desde as primeiras temporadas da expedição de Tel Aviv. Agora, em 2016, a escavação já havia descido até o estrato X, do período do início do Bronze Tardio I, cerca do ano 1550 AEC. Ou seja, começamos a escavar já no mesmo nível onde, perto dali, Schumacher escavou o palácio. 
Depois de limpar a área, que sempre leva um tempo considerado, começamos a escavar. De início, chegamos a pensar que estávamos escavando uma cozinha, pois encontrávamos muitos ossos de animais grandes e pequenos, algumas facas de pedra e muita cerâmica quebrada. Inclusive, cheguei a escrever um relatório para o Programa de Pós-Graduação em Ciências da Religião da minha Universidade nesse sentido. Contudo, aos poucos foram aparecendo entre a terra, que lentamente ia sendo retirada, grandes pedras empilhadas, sem imaginarmos o que poderia estar debaixo delas. A hipótese que prevalecia é que poderia se tratar de uma tumba, fato comum nos estratos desse período. Porém, o terreno escavado ia aprofundando e cada vez mais o "monumento" aumentava. Ou seja, ele era muito grande para se tratar de uma tumba, como as que comumente são descobertas em outras áreas.

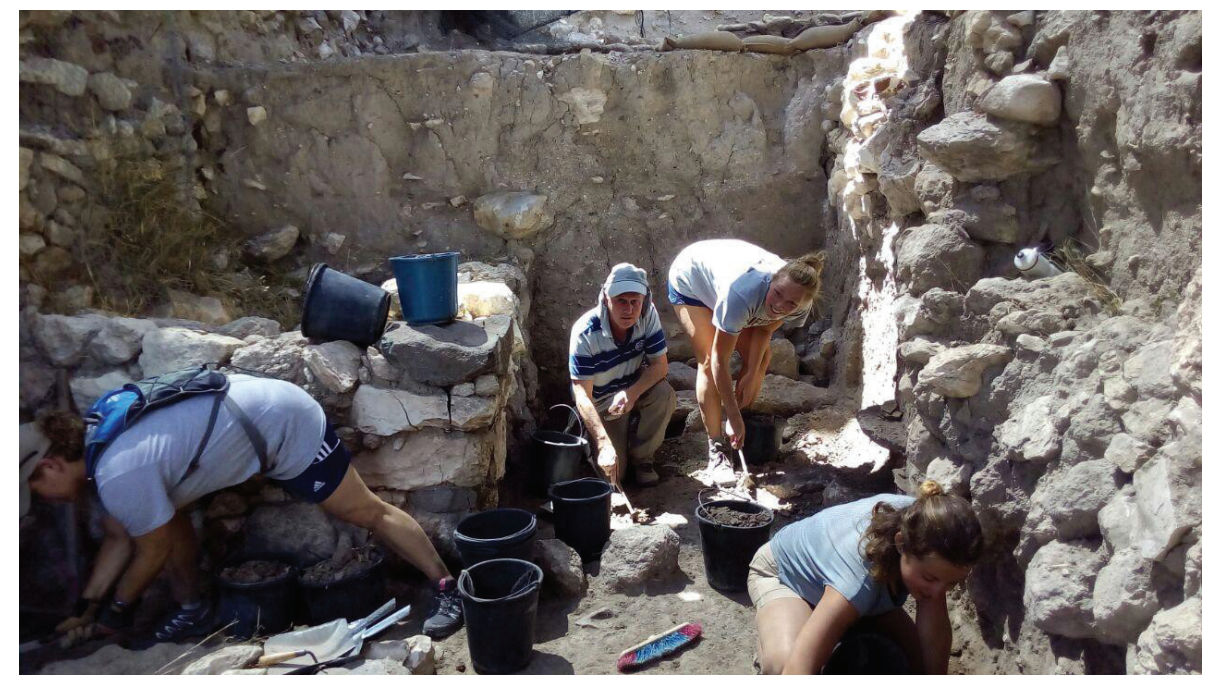

Estágio inicial, escavando sobre a tumba.

O trabalho era lento e cuidadoso. Eu havia sido encarregado de "articular" (to articulate) o "monumento", expressão que em inglês se refere a deixar o terreno escavado em boas condições para ser fotografado. Quando estava nesse processo de limpeza, apareceu Israel Finkelstein e do alto exclamou em bom e alto tom: "My dear friend, this is amazing!" (Meu querido amigo, isto é surpreendente!). Na verdade, nós, que estávamos no 
fundo da escavação, não tínhamos a real noção da dimensão e da estrutura do que estávamos escavando. Em todo caso, ainda não era possível imaginar o que havíamos encontrado.

Durante o processo de limpeza "articulação" foram aparecendo aberturas entre as pedras, onde a terra ia sendo retirada, o que permitiu que eu pudesse introduzir o meu celular e fotografar o seu interior. Isso não era permitido para os/as escavadores/as, porém, como eu era amigo do "big boss", ninguém se opôs. Analisando a foto, tive a impressão de que tínhamos encontrado um túnel de água, isso pelo tamanho do seu interior. Inclusive, saí da área de escavação e examinei a encosta do sítio para ver se ali havia sinais de um possível túnel de água. Chamei a coordenadora responsável, Dra. Melissa Cradic, e lhe disse que eu achava que tínhamos encontrado um túnel de água. "Por quê?”, perguntou ela. Então lhe mostrei a foto. Pouco depois veio o auxiliar dela com o seu celular preso a uma vareta e o introduziu pela mesma abertura e começou a filmar o interior. Porém, a estrutura interna das paredes não permitiu que as imagens pudessem revelar algo novo, de maneira que não avançamos em nossa busca por informações.

Quando atingimos a base do monumento, encontramos uma pedra grande, bastante rústica, que aparentava a entrada da estrutura. Foi também o tempo justo, pois a temporada da expedição 2018 já estava findando. Havia uma grande expectativa para se abrir e entrar na "tumba", mas, para isso era preciso todo um preparo sofisticado, possivelmente um novo projeto. O interesse de minha parte era permanecer por mais tempo no sítio, mas a passagem de regresso ao Brasil já estava comprada e o jeito era voltar. Perguntei ao prof. Finkelstein o que pensavam fazer. Ele disse que ainda não sabia ao certo, provavelmente cobrir a estrutura com cobertores, instalar detectores, colocar a terra removida de volta e retornar na próxima temporada. A explicação não me parecia muito convincente, mas foi exatamente o que ele disse. 


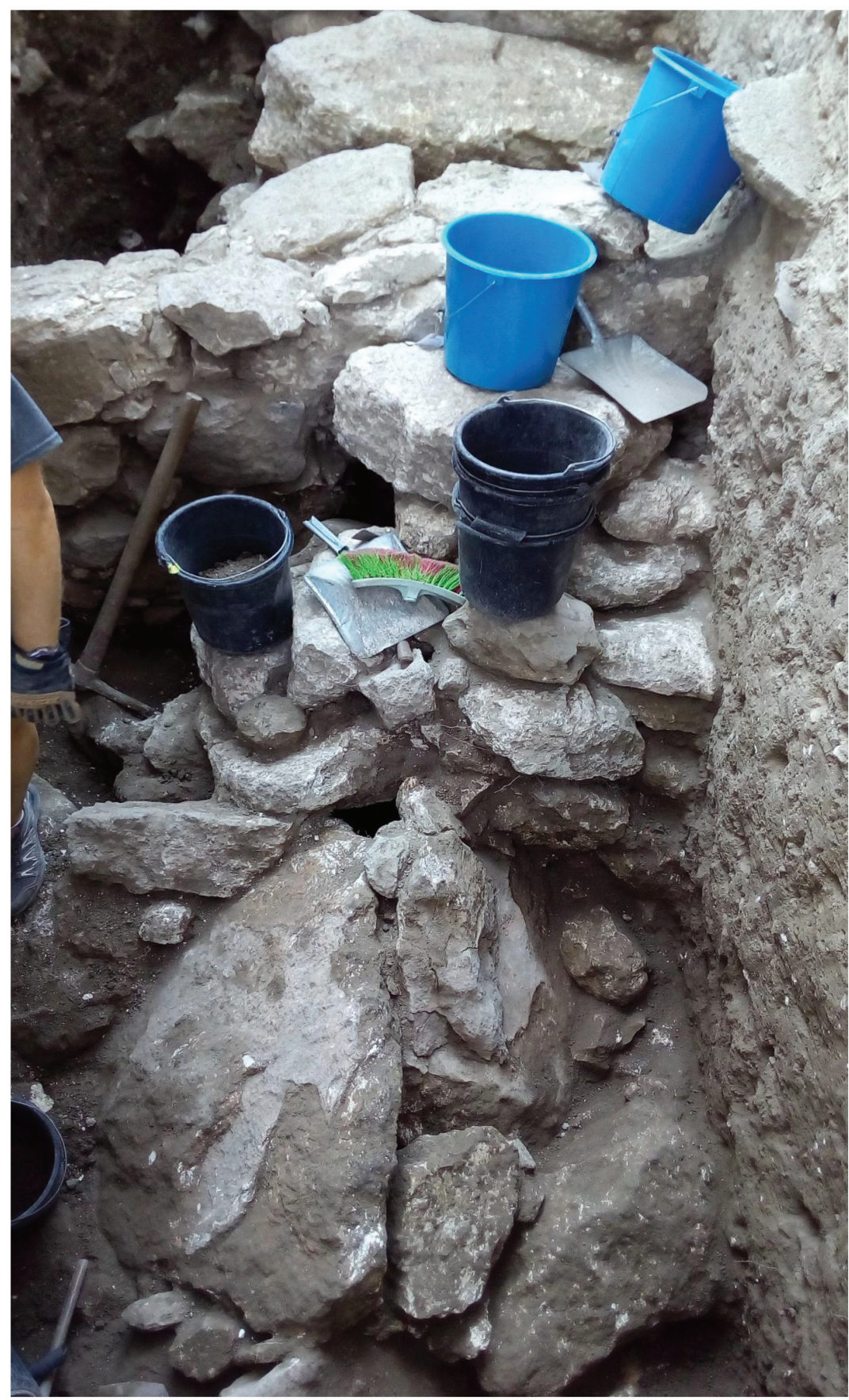

Fase final da escavação. Tumba vista de cima. 
Passado três semanas, já no Brasil, o prof. Finkelstein me escreveu dizendo que resolveram entrar na "tumba" com um pequeno grupo e que foram surpreendidos enormemente com o que encontraram: uma tumba real. Uma tumba real contendo três corpos: um homem, uma mulher e uma criança, com ricas joias, marfim e fina cerâmica. O homem usava um diadema, um colar e um bracelete, tudo em ouro.

Passado cerca de um ano, sem mais informações, tornei a escrever a Finkelstein perguntando se já haviam publicado algo a respeito, eu estava ansioso por notícias e evitava tornar público tanto as fotos, quanto o achado em si. Ele respondeu que não e que ainda estavam fazendo análises em laboratório etc., mas que estava sendo preparada uma reportagem em primeira mão para a National Geographic. E assim foi. A informação da descoberta da tumba real de Megiddo foi publicada com exclusividade pela National

Geographic no dia 13 de março de 2018. ${ }^{28}$ Alguns dias depois, dia 30 de abril, a descoberta também foi publicada pela Biblical Archaeology Society. ${ }^{29}$ Tínhamos encontrado a tumba real que G. Schumacher e os que se seguiram a ele estavam procurando desde 1903, a primeira em toda história da escavação de Israel e Palestina, das Eras do Bronze e do Ferro.

\subsection{Quem eram os proto-israelitas?}

Qual o primeiro impacto dessa descoberta? A descoberta da primeira tumba real das Eras do Bronze e do Ferro em toda história de escavação de Israel e Palestina vai possibilitar conhecer melhor a população de Canaã antes do surgimento do Israel bíblico, os proto-israelitas. Nas palavras de Israel Finkelstein: "Esse estudo tem o potencial de revolucionar o que sabemos sobre a população de Canaã antes do mundo da Bíblia". ${ }^{30}$ Pela primeira vez se poderá estudar o DNA, ciência em ascensão no fazer arqueologia moderna, das pessoas que formavam a elite das cidades-Estado de Canaã e compará-lo com o DNA dos corpos de pessoas "comuns" desta

\footnotetext{
28 Cf.: https://news.nationalgeographic.com/2018/03/megiddo-armageddon-dna-royal-burialcanaan- archaeology/.

29 Cf: http://reply.biblicalarchaeology.org/dm?id=4081D92D708BB05B342FD0FB3B52B1 AC7155B6 9F94C9C0E3

30 "These studies have the potential to revolutionize what we know about the population of Canaan before the rise of the world of the Bible" (National Geographic).
} 
época e que constantemente são encontrados nas escavações dos sítios arqueológicos da região. Isso é relevante, pois se acredita que a elite que reinava nas cidades-Estado de Canaã nas Eras do Bronze Médio e Tardio era formada pelos hurritas, um povo de cultura avançada e que teve um papel determinante no surgimento e estruturação das primeiras cidades-Estado no Levante (YOUNGER, 2016, p. 35-107; LIVERANI, 2016, p. 229-230; GENZ, 2013, p. 469-477). A análise do DNA dos corpos da tumba real vai permitir a comprovação se esta tese se sustenta ou não.

Entre as cartas de Tell el-Amarna (MORAN, 1992; RAINEY, 2015) foram encontradas sete cartas enviadas pelo governante de Megiddo ao rei do Egito (EA 242-246 e EA 365). ${ }^{31} \mathrm{O}$ nome do governante era Biridiya e o tema fundamental tratado nas cartas eram os constantes ataques que Megiddo, nesse tempo uma base militar egípcia, sofria de Lab’ayu, governante da cidade-Estado de Siquém e que se havia rebelado contra o domínio egípcio. Em uma das cartas (EA 245), Biridiya relata ao rei do Egito a captura de Lab'ayu e sua posterior morte. Essas cartas foram escritas entre 1390-1336 AEC. ${ }^{32}$ Portanto, cerca de duzentos anos depois do reinado do rei, cuja ossada encontramos em 2016, e de quem Biridiya deve ter sido descendente.

\section{Considerações finais}

Megiddo, por causa de sua localização estratégica, junto a uma das mais importantes vias internacionais do Antigo Oriente Próximo, foi centro de disputa milenar. Esse fator faz Megiddo ser um Tel único em todo Levante. As constantes destruições e reconstruções determinam a excelência de sua estratigrafia, propícia para a arqueologia, pois permite que se estude, com bastante precisão, os períodos históricos de mais de cinco séculos. É por isso que Megiddo está sendo escavada por mais de cem anos.

A primeira expedição aconteceu em 1903-1905 e foi conduzida pela Associação Alemã para a Exploração da Palestina, sob a direção do engenheiro e arqueólogo Gottlieb Schumacher. A segunda e maior expedição aconteceu em 1925-1938, organizada pelo Instituto Oriental de Chicago. Foram treze anos sucessivos de escavação, divididos em três

\footnotetext{
$\overline{31}$ A sétima carta (EA 247), muito danificada, cuja escrita e cerâmica indicam ser sua origem de Megiddo. Contudo, há dúvida sobre o autor dessa carta, se se trata de Yashdata (MORAN, 1987, p. 301) ou de Biridiya (RAINEY, 2015, p. 1.564).

32 Período em que o Egito foi governado por Amenhotep III e Amenhotep IV (Akenaton).
} 
períodos, cada um dirigido por um diretor diferente. De 1925-1927, por Clarence Stanley Fisher; de 1927-1935, por Philip Langstaffe Ord Guy; de 1935-1938, por Gordon Kenneth Loud. A terceira expedição aconteceu sob a responsabilidade da Universidade hebraica de Jerusalém, durante os anos de 1960, 1966-1967 e 1971-1972. Foram temporadas bastante breves, com grupos bem reduzidos e coordenados pelo arqueólogo e professor Yigael Yadin. Com Yadin se inicia um novo tempo na arqueologia da Palestina, agora controlada pelo Estado de Israel, com interesse político-ideológico. A quarta expedição é conduzida pelo Departamento de Arqueologia da Universidade de Tel Aviv, 1992-2018, tendo à frente os arqueólogos Israel Finkelstein e David Ussishkin. Um dos grandes feitos da equipe de Tel Aviv foi a construção da teoria da baixa cronologia.

Participar desta história é um privilégio. Escavar uma tumba real vai além do privilégio. É sentir que o estudo bíblico-arqueológico no Brasil vai alcançando o patamar da contribuição. Os resultados ainda precisam ser depurados, mas já está assegurado que temos novos elementos para estudar o contexto do povo cananeu prévio a Israel.

\section{Referências}

CLINE, Eric. Three Stones Make a Wall: the story of archaeology. Princeton: Princeton University Press, 2017.

DAVIS, Thomas W. Shifting Sands: the rise and fall of Biblical Archaeology. London: Oxford Academic Press, 2004.

FINKELSTEIN, Israel. Hazor and the North in the Iron Age: A Low Chronology Perspective. BAZOR, 314, 1999, p. 55-70.

FINKELSTEIN, Israel. O Reino Esquecido - Arqueologia e História de Israel Norte. São Paulo: Paulus, 2015.

FINKELSTEIN, Israel. The Stratigraphy and Chronology of Megiddo and Bethshan in the 12-11th Centuries B.C.E. Tel Aviv, 23, 1996, p. 170-184.

FINKELSTEIN, Israel; USSISHKIN, David; CLINE, Eric H. MEGIDDO V: The 2004-2008 Seasons (2 vols.). Monograph Series, n. 31. Tel Aviv: Tel Aviv University Press, 2013.

FINKELSTEIN, Israel; USSISHKIN, David; HALPERN, Baruch. MEGIDDO IV: The 19982002 Seasons (2 vols.). Monograph Series, n. 24. Tel Aviv: Tel Aviv university Press, 2006.

FINKELSTEIN, Israel; USSISHKIN, David; HALPERN, Baruch. MEGIDDO III: The 19921996 Seasons (2 vols.). Monograph Series, n. 24. Tel Aviv: Tel Aviv university Press, 2000.

FISHER, Clarence S. The Excavation of Armageddon. The University of Chicago. Oriental Institute Communications. No.09. Chicago, Illinois: The University of Chicago Press, 1929. 
FRANKLIN, Norma. Megiddo and Jezreel Reflected in the Dying Embers of the Northern Kingdom of Israel. Shuichi Hasegawa, Christoph Levin and Karen Radner (Orgs.). The Last Days of the Northern Kingdom of Israel. Berlin/Boston: Walter de Gruyter, 2018, p. 189-208.

FUNARI, Pedro Paulo. Arqueologia. São Paulo: Editora Contexto, 2010.

GENZ, H. "No Land Could Stand Before Their Arms, from Hatti...on..."? New Light on the End of the Hittite Empire and the Early Iron Age in Central Anatolia. A. E. Killebrew and G. Lehmann (Orgs.). The Philistines and Other "Sea Peoples" in Text and Archaeology. Atlanta: SBL, 2013, p. 469-467.

GERBER, Haim. State, Society, and Law in Islam: Ottoman Law in Comparative Perspective. New York: State University of New York Press, 1994.

GUY, P. L. O. New Light from Armageddon. Second Provisional report (1927-29) on the Excavations at Megiddo in Palestine. The University of Chicago. Oriental Institute Communications, n. 9. Chicago, Illinois: The University of Chicago Press, 1931.

KAEFER, José Ademar. Arqueologia das terras da Bíblia I e II. São Paulo: Paulus, $2012 / 2016$.

KAEFER, José Ademar. As Cartas de Tell El-Amarna e o contexto egípcio nos reinados de Amenhotep III e Amenhotep IV (Akenaton). Estudos da Religião, vol. 32, n. 1. São Bernardo do Campo: Metodista, 2018, p. 121-140.

LIVERANI, M. Antigo Oriente - História, Sociedade e Economia. São Paulo: Edusp, 2016.

LOUD, Gordon. The Megiddo Ivories. The University of Chicago. Oriental Institute Publications. Vol. LII. Chicago, Illinois: The University of Chicago Press, 1939.

MARTINI, Mario A. S. The Fate of Megiddo at the End of the Late Bronze IIB. Oded Lipschits; Yuval Gadot; Matthew J. Adams (Orgs.). Rethinking Israel - Studies in the history and archaeology of ancient Israel in honor of Israel Finkelstein. Wininona Lake: Eisenbrauns, 2017, p. 267-286.

MENDONÇA, Elcio V. S. A Dinastia Omrida. Reconstrução do Primeiro Estado Independente de Israel a partir da Bíblia e da Arqueologia. Tese (Doutorado em Ciências da Religião). Programa de Pós-Graduação em Ciências da Religião. São Bernardo do Campo: Universidade Metodista de São Paulo, UMESP, 2017.

MORAN, William. The Amarna letters. Baltimore/London: The Johns Hopkins University Press, 1992.

MYNAROVÁ, Jana. Discovery, research and excavation of the Amarna Tablets - The formative stage. RAINEY, Anson F. The El-Amarna Correspondence - "A new Edition of the Cuneiform Letters from de Site of El-Amarna based on Collations of all Extant Tablets". Leiden-Boston: Brill, 2015, p. 37-46.

RAINEY, Anson. The El-Amarna Correspondence - A new Edition of the Cuneiform Letters from de Site of El-Amarna based on Collations of all Extant Tablets. LeidenBoston: Brill, 2015. 
ROBINSON, Edward. Biblical Researches in Palestine and in the Adjacent Regions: a journal of travels in the year 1838. Vol. II. Boston: Crocker and Brewster, 1856. SCHUMACHER, G. Tell el-Mutesellim I. Leipzig: Hinrichs, 1908.

USSISHKIN, David. Megiddo-Armageddon. The Story of the Canaanite and Israelite City. Jerusalém: Israel Exploration Society; Biblical Archaeology Society, 2018. YADIN, Yigael. New Light on Solomon's Megiddo. Biblical Archaeology, n. 23, p. 62-68, 1960.

YADIN, Yigael. Megiddo of the Kings of Israel. Biblical Archaeology, vol. 33, p. 66-96, 1970.

YADIN, Yigael. Solomon's City Wall and Gate at Gezer. IEJ, n. 8, p. 80-86, 1958. YOUNGER, K. Lawson. A political history of the Arameans - From their origins to the end of their polities. Atlanta: SBL Press, 2016. https://news.nationalgeographic.com/2018/03/megiddoarmageddon-dna-royal-burial- canaan-archaeology/ http://reply.biblicalarchaeology.org/ dm?id=4081D92D708BB05B342FD0FB3B52B1 A C7155B69F94C9C0E3 https://www.pef. org.uk/profiles/gottlieb-schumacher. Acesso em 23/10/2018.

https://sites.google.com/site/megiddoexpedition/dig-megiddo-2016 https://megiddoexpedition.wordpress.com/ http://dgp.cnpq.br/dgp/ espelhogrupo/4338921870858325 http://portal.metodista.br/arqueologia https:// metodista.academia.edu/JoséAdemarKaefer

Submetido em: 31-12-2018

Aceito em: 11-4-2019 